\title{
Algoritma Berhitung Blijâh: Alternatif Pembelajaran Operasi Penjumlahan dan Pengurangan
}

\author{
Loviga Denny Pratama ${ }^{1)}$, Wahyu Setyaningrum ${ }^{2)}$ \\ ${ }^{1), 2)}$ Universitas Negeri Yogyakarta \\ E-mail: loviga.pratama@gmail.com ${ }^{1)}$,wahyu_setyaningrum@uny.ac.id ${ }^{2}$
}

\begin{abstract}
The aim of this study was to describe arithmetic algorithm on transaction employed by Blijâh. The study was a qualitative approach by means of case study in Madurese community. The data were gathered through observation and interviews. The partisipants of this study were 8 Blijâh living in Paiton, Probolinggo. The data were analyzed using Miles \& Huberman model. The results of this study obtained some arithmatics algorithm of addition, subtraction, multipication, and division. This paper, however, will only focus on addition and subtraction algorithm. The data reveals that there are several differences in the algorithm used by Blijâh and the one taught at school. The results of this study could be used as one of teaching and learning approach to develop numerical and mental calculation skills.
\end{abstract}

Keywords: arithmetics algorithm, Blijâh, addition, subtraction

\section{PENDAHULUAN}

Matematika merupakan cabang ilmu pengetahuan yang banyak mengandung perhatian berbagai elemen dari aspek kehidupan. Matematika merupakan alat dan ilmu pendukung bagi cabang ilmu lainnya untuk mendapatkan solusi dari berbagai permasalahan yang timbul, selain itu matematika juga sangat berguna dalam kaitannya dengan kehidupan sehari-hari. Ubayanti, Lumbantobing, \& Manurung (2016) mengemukakan bahwa matematika tumbuh dan berkembang karena adanya tantangan hidup yang dihadapi manusia di berbagai wilayah dengan latar belakang masyarakat yang berbeda, misalnya pada nelayan masyarakat Papua Barat, mereka mengembangkan matematika dengan cara mereka sendiri selama pembuatan Sero Kokas Fakfak. Oleh karena itu, matematika dipandang sebagai hasil akal budi atau pikiran manusia dalam aktivitas masyarakat sehari-hari. Maka berakibat bahwa penguasaan terhadap matematika mutlak diperlukan dan konsep-konsep dalam matematika harus dipahami secara benar sejak dini.
Petocz dan Reid (2003) mengungkapkan bahwa matematika merupakan penyusun dari komponen individu yang memusatkan perhatian terhadap aktivitas matematika termasuk dugaan perhitungan. Pendapat tersebut telah tercermin dalam kehidupan masyarakat yang telah melakukan berbagai aktivitas-aktivitas matematika. Misalnya pada aktivitas jual-beli, masyarakat menggunakan konsep matematika yaitu berhitung untuk menghitung uang kembalian, menghitung laba atau rugi, dan lainlain. Selain berhitung, masyarakat juga melakukan aktivitas matematika seperti membilang atau menyatakan banyaknya sesuatu, serta aktivitas mengukur (mengukur luas sawah, mengukur atau menimbang banyaknya beras, dan lainlain). Hal ini diperjelas oleh pendapat Hartoyo (2012) yang menyatakan meskipun masyarakat tidak paham matematika, namun mereka menerapkan konsep matematika yang rumit diterapkan pada aktivitas kesehariannya. Aktivitas-aktivitas tersebut hendaknya dieksplorasi agar masyarakat dapat mengetahui bahwa aktivitas-aktivitas 
yang mereka lakukan selama ini berkaitan dengan konsep dasar matematika. Selain itu juga agar dapat menjadi referensi bagi para pendidik dalam mengajarkan matematika agar lebih realistik yaitu dengan menghubungkannya dengan kehidupan sehari-hari yang ada di masyarakat tersebut.

Menurut Sirate (2012), sebagian besar peserta didik mengakui matematika itu penting, namun sebagian dari mereka sering mengalami kesulitan dalam mempelajarinya. Persoalan ini muncul karena adanya ketidaksesuaian yang mereka temukan di luar sekolah yaitu di rumah dan di masyarakat dengan apa yang mereka temukan di sekolah. Barta \& Shockey (2006) mengakui pula adanya gejala-gejala yang memunculkan wajah seram matematika, sehingga peserta didik menganggap matematika sebagai pelajaran yang membosankan, kurang menarik, dan jauh dari kehidupan sehari-hari. Gejala tersebut biasanya muncul saat siswa mulai mengeluh dengan banyaknya rumus-rumus yang diberikan oleh guru saat pembelajaran berlangsung.

Menurut Hilbert dan Carpenter (1992), pembelajaran matematika di sekolah terlalu bersifat formal dan berbeda dengan yang ditemukan dalam kehidupan sehari-hari, sehingga matematika dipandang sebagai mata pelajaran yang sulit oleh perserta didik. Oleh karena itu sangat penting untuk menggali konsep-konsep matematika yang terdapat dalam kehidupan seharihari sehingga konsep tersebut dapat membantu peserta didik dalam mempelajari matematika di sekolah dan juga sebaliknya konsep matematika dapat membatu memecahkan permasalahan yang mereka temui sehari-hari. Namun pada kenyataannya, lingkungan belajar yang ada saat ini cenderung kurang melibatkan koteks yang familiar bagi siswa. Sebagian besar pembelajaran matematika hanya menjadikan dunia nyata sebagai sarana untuk mengaplikasikan konsep yang terkadang dipaksakan, bukan sarana untuk mengembangkan kreatifitas siswa dalam membangun atau membentuk konsep.

Salah satu konsep dasar dalam pembelajaran matematika yaitu algoritma berhitung. Melakukan algoritma berhitung selain membutuhkan kemampuan matematika, juga membutuhkan keterampilan dan ketelitian dalam berhitung. Agar siswa dapat melakukan algoritma berhitung dengan baik, maka siswa harus menguasai konsep, mempunyai keterampilan dalam berhitung serta mengetahui strategi berhitung. Berkaitan dengan ini, Salma dan Amin (2014) mengungkapkan beberapa strategi dalam berhitung, (1) front-end estimation yang fokusnya pada front end atau angka paling kiri. Karena angka ini adalah yang paling penting untuk membentuk penaksiran. Contoh $5,6+2,1+6,7+8,1$ diestimasi menjadi $5+2+6+8=21$; (2) adjusting, strategi ini dapat digunakan bersamaan dengan semua strategi estimasi dan semua jenis operasi. Misal adjusting with front-end estimation, 5, $6+2,4+$ $6,7+8,3$ diestimasi menjadi $5+2+6+$ $8=21$, angka yang dibelakang koma disesuaikan $0,6+0,4=1$ dan $0,7+0,3$ =1. Jadi, $21+2=23$; (3) compatible numbers dimana strategi ini melibatkan pemilihan angka untuk membuat perhitungan agar lebih mudah. Angkaangka yang dipilih akan diubah atau disesuaikan, sehingga dapat dipasangkan dengan angka yang lain. Contoh $24+46+34+63+53+86,24$ $+86 \approx 100,63+34 \approx 100$, dan $46+$ $563 \approx 100$, sehingga hasilnya kurang lebih 300; (4) clustering dimana strategi 
ini melibatkan penambahan banyak bilangan secara bersama-sama ketika bilangan-bilangan tersebut semua di sekitar nilai tertentu. Misalnya $392+$ $420+391+414$, ke empat bilangan tersebut nilainya sekitar 400 , sehingga 4 $\times 400=1.600 ;$ dan $(5)$ rounding dimana strategi ini melibatkan pembulatan angka dan perhitungan dengan bilangan bulat. Misal $47 \times 63$ diestimasi menjadi $50 \times 60=3000$. Strategi-strategi tersebut jarang kita jumpai di sekolah pada saat siswa mengerjakan soal. Hal ini dikarenakan dalam berhitung pada umumnya siswa diajarkan dengan menggunakan teknik bersusun panjang dan bersusun pendek.

Pada studi ini subjek yang dipilih oleh peneliti adalah pedagang sayur keliling berasal dari suku Madura yang yang tinggal di pulau Madura dan pulau-pulau sekitarnya, dapat dilihat pada Gambar 1.

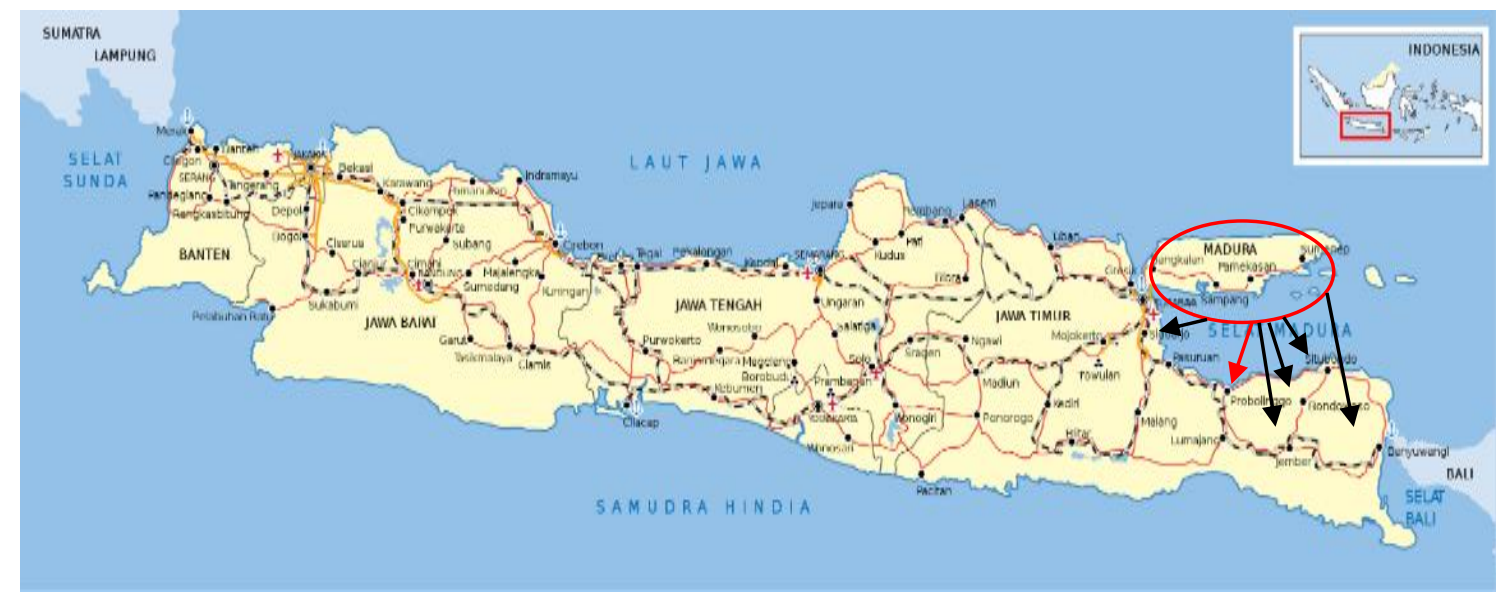

Gambar 1. Geografis Pulau Madura di Indonesia dan Distribusi

Suku ini merupakan suku yang terkenal dengan budaya merantau. Adanya budaya tersebut dikarenakan daerah yang mereka tinggali merupakan salah satu daerah dengan ekonomi rendah di Indonesia. Perantauan mereka ke luar daerah utamanya untuk memperbaiki kondisi ekonomi keluarga mereka. Kebanyakan dari mereka merantau di pulau jawa diantaranya di Surabaya, Probolinggo, Bondowoso, Jember, Situbondo, dan Banyuwangi (Sutoko, 1998). Sehingga mengakibatkan pada daerah probolinggo banyak ditemukannya masyarakat etnis Madura. Pilihan berdagang biasanya diambil oleh perantau Madura di kota-kota besar Negeri ini. Hal ini dikarenakan sejak kecil telah menanamkan pemikirannya untuk berdagang (Rifai, 2007). Melalui berdagang ini berdampak pada kemampuan hitung cepat dikarenakan setiap hari mereka melakukan transaksi jual beli yang tidak lepas kaitannya dengan berhitung. Hal ini juga akan timbul strategi-strategi berhitung yang digunakan saat proses transaksi jualbeli. Oleh karena itu, penelitian difokskan pada strategi perhitungan yang digunakan oleh penjual sayur tradisional dari Madira di Probolinggo yang dikenal dengan sebutan Blijâh.

Alasan memilih Blijâh sebagai subjek dikarenakan peneliti menemukan adanya keunikan yang dilakukan oleh Blijâh pada saat melakukan transaksi dengan pembelinya. Salah satu transaksi yang dilakukan adalah menghitung total uang belanja para pembeli. Blijâh 
menghitung dengan cepat tanpa menggunakan kalkulator maupun alat bantu hitung lainnya. Tentunya mereka memiliki cara-cara tersendiri dalam menjumlahkan, mengurangkan, mengalikan atau membagi. Hal ini dibuktikan ketika peneliti pernah mengamati salah satu Blijâh di kecamatan Paiton yang sedang memberi uang kembalian kepada pembeli. Pada saat itu jumlah total belanja yang harus dibayar oleh si pembeli adalah $\mathrm{Rp}$ 23.000,00 dan pembeli membayar dengan uang senilai Rp 50.000,00. Saat memberi uang kembalian, tahap awal yang diberikan oleh Blijâh adalah uang sebesar Rp 7.000,00 untuk menggenapi total belanja pembeli sehingga menjadi Rp 30.000,00 dan selanjutnya Blijâh menambahkan dengan uang $\mathrm{Rp}$ $20.000,00$ sehingga total uang menjadi Rp 50.000,00 kembali. Dengan cara tersebut maka dapat diketahui bahwa kembalian yang diberikan kepada pembeli adalah Rp 27.000,00. Dari aktivitas tersebut sudah terlihat bahwa cara pengoperasian bilangan yang dilakukan oleh Blijâh berbeda dengan cara yang diajarkan di sekolah. Marzuki (2011) mengungkapkan bahwa cara mengoperasikan suatu bilangan yang dipelajari di sekolah, dilakukan dengan cara bersusun panjang dan bersusun pendek yaitu langsung mengoperasikan antara satuan dengan satuan, puluhan dengan puluhan, ratusan dengan ratusan, dan seterusnya yang sesuai dengan tempatnya. Namun demikian, pada kenyataannya masih ditemukan beberapa cara yang digunakan masyarakat dalam berhitung yang berbeda dengan yang dipelajari di sekolah. Oleh karena itu dengan adanya studi ini diharapkan dapat mengungkap aspek-aspek matematika yang terdapat pada algoritma berhitung Blijâh. Sehingga dapat digunakan sebagai salah satu alternatif cara atau metode pembelajaran matematika khususnya berhitung. Sehingga siswa dapat mengetahui berbagai macam cara atau strategi berhitung.

\section{METODE PENELITIAN}

Daerah yang digunakan dalam studi ini bertempat di Kecamatan Paiton Probolinggo yang akan dicapai melalui studi kualitatif dengan pendekatan studi kasus. Subjek yang digunakan adalah masyarakat di Kecamatan Paiton yang berprofesi sebagai Blijâh. Alasan pemilihan daerah studi di Paiton karena kecamatan tersebut merupakan salah satu kecamatan yang mayoritas masyarakatnya berbahasa Madura dalam melakukan aktivitas kesehariannya dan pada daerah ini banyak anak usia sekolah yang berpikir bahwa matematika itu sulit dan tidak ada kaitannya dengan kehidupan seharihari.

Data mengenai algoritma berhitung pada Blijâh dikumpulkan dengan teknik observasi dan wawancara. Sumber data adalah 8 orang Blijâh. Pemilihan partisipan dilakukan peneliti dengan cara bertanya kepada masyarakat setempat khususnya ibu-ibu dan beberapa penjual di pasar. Sedangkan instrumen yang dibuat berdasarkan pengamatan awal yang telah dilakukan oleh peneliti mengenai proses transaksi jual beli yang dilakukan oleh Blijâh dan pembeli terutama dalam proses menghitung penjumlahan, pengurangan, perkalian, dan pembagian. Pedoman observasi digunakan sebagai pedoman peneliti dalam melakukan observasi kepada Blijâh saat melakukan transaksi jual beli dengan pembeli. Sedangkan pedoman wawancara digunakan untuk memberikan garis besar pertanyan-pertanyaan yang ditanyakan kepada Blijâh saat melakukan wawancara dengan kata lain wawancara semi terstruktur. 
Data dari observasi dan wawancara kemudian dianalisis dengan cara mengelompokkan data hasil studi yang kemudian direduksi dan disajikan sesuai fokus kajian masalah dan tujuan studi. Analisis data dilakukan dengan menggunakan model Miles \& Huberman (1994) yang terdiri dari tiga alur kegiatan yaitu reduksi data, penyajian data, dan penarikan kesimpulan. Dimana fokus analisis data pada artikel ini mendeskripsikan algoritma berhitung penjumlahan dan pengurangan yang dilakukan Blijâh dalam lingkup masyarakat Madura di Probolinggo.

\section{HASIL PENELITIAN DAN PEMBAHASAN}

Hasil observasi dan wawancara mencakup aktivitas berhitung yang kemudian di analisis dan dikaji. Data yang telah diperoleh dan telah dianalisis kemudian direduksi dan disajikan untuk mendapatkan kesimpulan akhir. Data tersebut diperoleh dari 8 subjek penelitian yang kemudian disebut $\mathrm{S} 1$, S2, S3, S4, S5, S6, S7, dan S8 yang berprofesi sebagai Blijâh di Kecamatan Paiton Probolinggo.

Dalam proses jual-beli, Blijâh melakukan aktivitas menghitung yang meliputi penjumlahan pengurangan, perkalian, dan pembagian. Pada umumnya, sebagian besar Blijâh tidak menggunakan atau menyebut bilangan menggunakan Bahasa Indonesia, melainkan menggunakan Bahasa Madura. Dalam transaksi jual beli, Blijâh maupun pembeli cenderung melakukan penghitungan dengan mengabaikan angka 0 sebagai ribuan. Berikut penjelasan teknik algoritma berhitung yang dilakukan oleh Blijâh secara detail untuk setiap operasi bilangan penjumlahan dan pengurangan.

\section{Penjumlahan}

Algoritma penjumlahan dapat dilihat ketika Blijâh menghitung total belanja pembeli. Bedasarkan hasil wawancara, ada tiga klasifikasi penjumlahan yaitu, penjumlahan yang keduanya tidak mengandung unsur limaratusan, penjumlahan yang salah satunya mengandung unsur limaratusan, dan penjumlahan yang keduanya mengandung unsur limaratusan.

\section{Penjumlahan Keduanya Tidak}

Mengandung Unsur Limaratusan

Jika kedua bilangan yang dijumlahkan adalah pulahan ribuan, misalnya $32.000+19.000$. Blijâh munjumlahkan puluh ribuan dengan puluh ribuan maka $30+10=40$. Kemudian menjumlahkan ribuan dengan ribuan $2+9=11$. Kemudian menjumlahkan hasil dari penjumlahan puluh ribuan dengan hasil penjumlahan ribuan yaitu $40.000+11.000=$ 51.000. Cara pengoperasian tersebut dapat dilihat pada Gambar 2. 


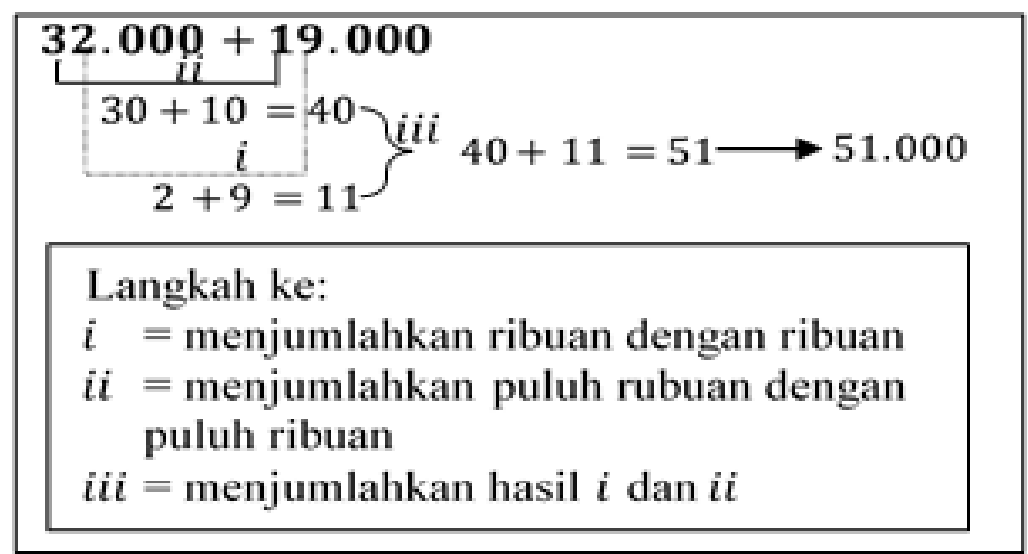

Gambar 2. Cara 1 Penjumlahan

Cara yang berbeda, jika bilangan yang dijumlahkan adalah puluh ribuan dan ribuan, misalnya $18.000+5.000$. Blijâh menggenapkan 18 ke 20 dengan cara mengambil 2 dari 5 sehingga 5 $2=3$. Jadi $18.000+5.000=20.000+$ $3.000=23.000$. Cara pengoperasian tersebut dapat dilihat pada Gambar 3 .

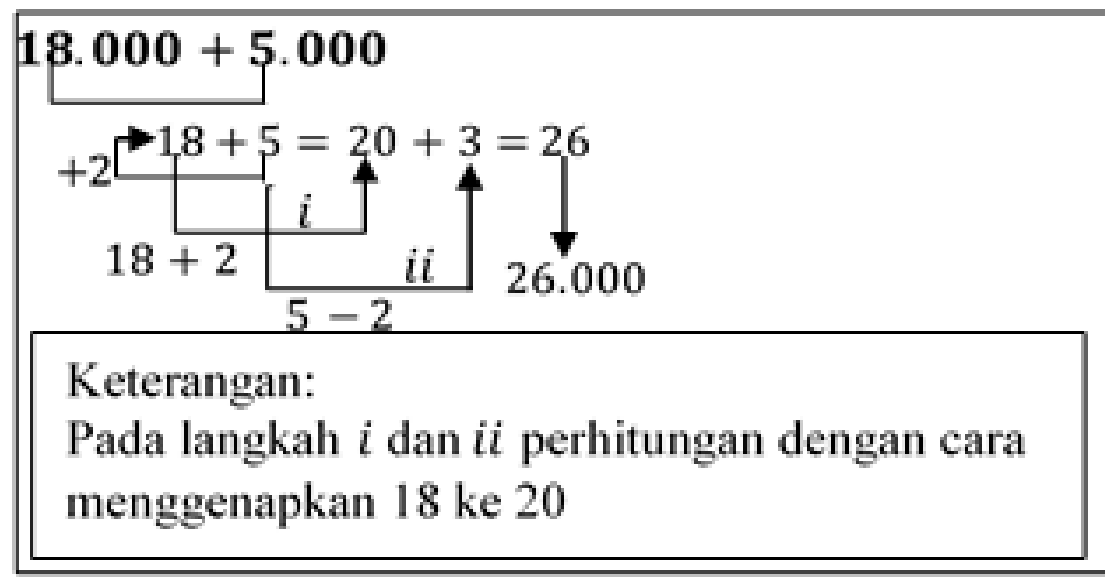

Gambar 3. Cara 2 Penjumlahan

\section{Penjumlahan salah satunya mengandung unsur limaratusan}

Apabila yang dijumlahkan mempunyai salah satu unsur limaratusan, terdapat 3 cara yang ditemukan. Cara pertama misalnya menghitung $24.000+9.500$. Terlebih dahulu Blijâh menjumlahkan ribuan dengan ribuan yaitu $4+9=13$, lalu menjumlahkan puluh ribuan dengan hasil penjumlahan tersebut yaitu $20+$ $13=33$. Kemudian menjumlahkan $33.000+500=33.500$ yang berarti Blijâh mengoperasikan 500 di akhir operasi. Cara pengoperasian tersebut dapat dilihat pada Gambar 4. 
ISSN 2089-8703 (Print) Vol. 7, No. 1 (2018)

ISSN 2442-5419 (Online)

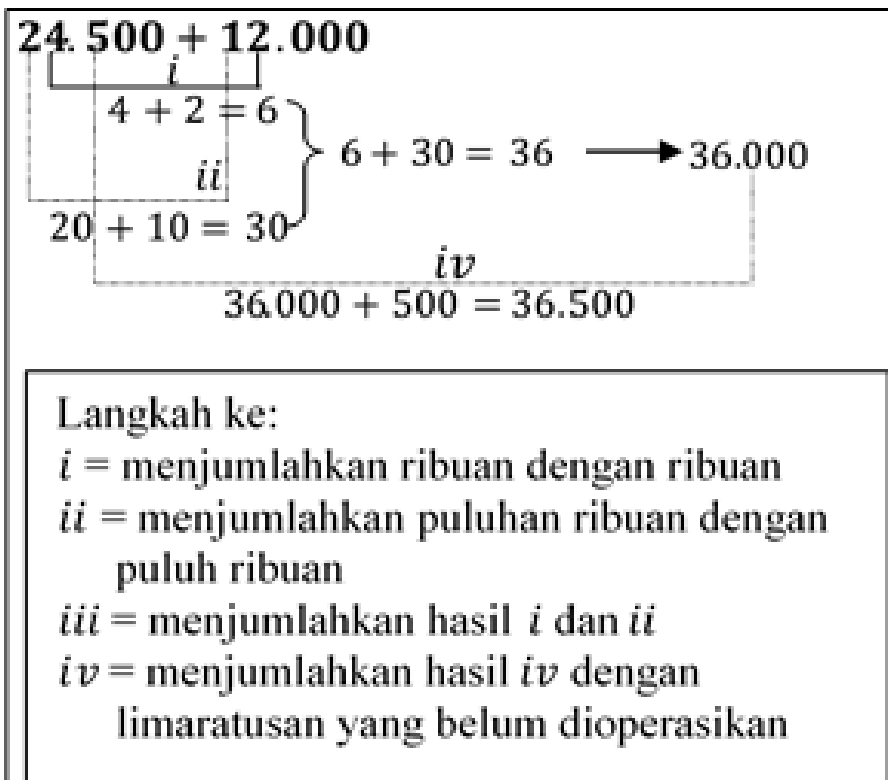

Gambar 4. Cara 1 Penjumlahan

Pada cara kedua, misalnya menghitung $28.500+16.000$. Blijâh menggenapkan 28.500 ke 30.000 dengan cara mengambil 1.500 dari 16.000 sehingga $16.000-1.500=$
14.500. Jadi $28.500+16.000=30.000$ $+14.500=44.500$. Cara pengoperasian tersebut dapat dilihat pada Gambar 5.

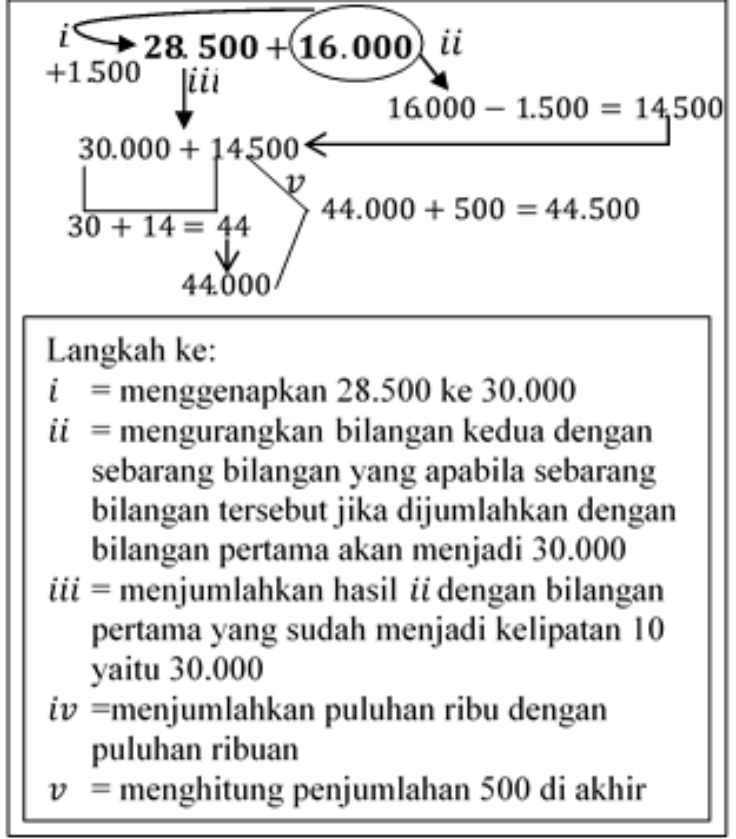

Gambar 5. Cara 2 Penjumlahan

Sedangkan pada cara ketiga, misalnya menghitung $23.500+12.000$. Blijâh menjumlahkan puluh ribuan yang kedua dengan bilangan pertama yang dijumlahkan yaitu $23+10=33$. Kemudian menjumlahkan bilangan 
ISSN 2089-8703 (Print) Vol. 7, No. 1 (2018)

ISSN 2442-5419 (Online)

limaratusan dengan bilangan ribuan mengoperasikan $33.000+2.500=$ yang belum dijumlahkan yaitu $500+$ $2.000=2.500$. Sehingga Blijâh 35.500. Cara pengoperasian tersebut dapat dilihat pada Gambar 6.

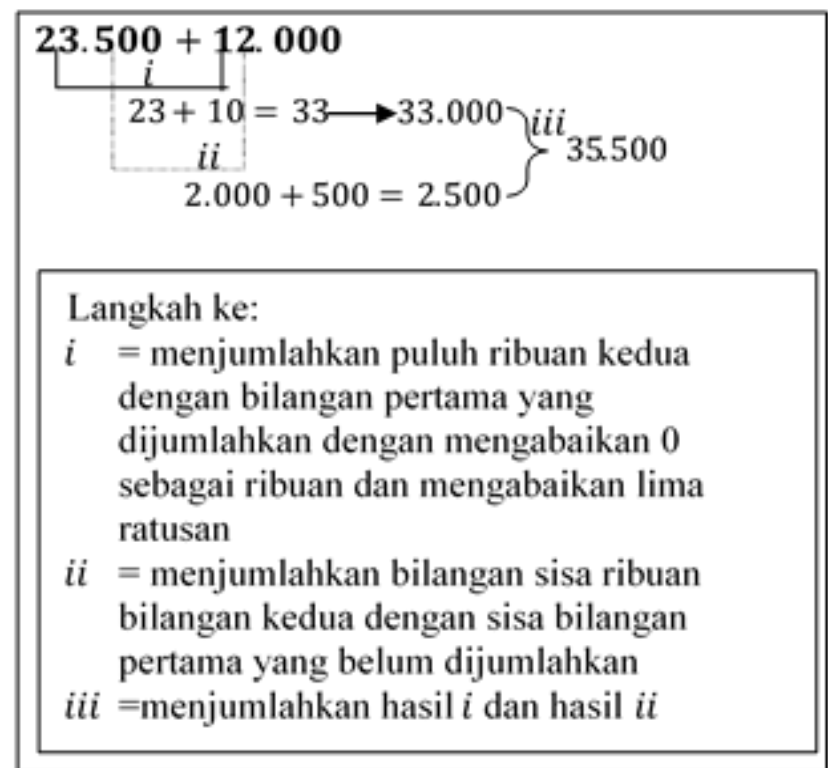

Gambar 6. Cara 3 Penjumlahan

Penjumlahan Keduanya Mengandung Unsur Limaratusan

Apabila yang dijumlahkan kedua bilangannya mengandung unsur limaratusan, terdapat 3 cara yang ditemukan. Cara pertama, Misalnya Blijâh menghitung $27.500+4.500$. Blijâh mengabaikan 0 sebagai ribuan dan terlebih dahulu mengabaikan limaratusan sehingga $27+4=31$. Kemudian Blijâh mengoperasikan 500 dengan 500 yaitu $500+500=1.000$. Sehingga langkah terakhir $31.000+$ $1.000=32.000$. Cara pengoperasian tersebut dapat dilihat pada Gambar 7.

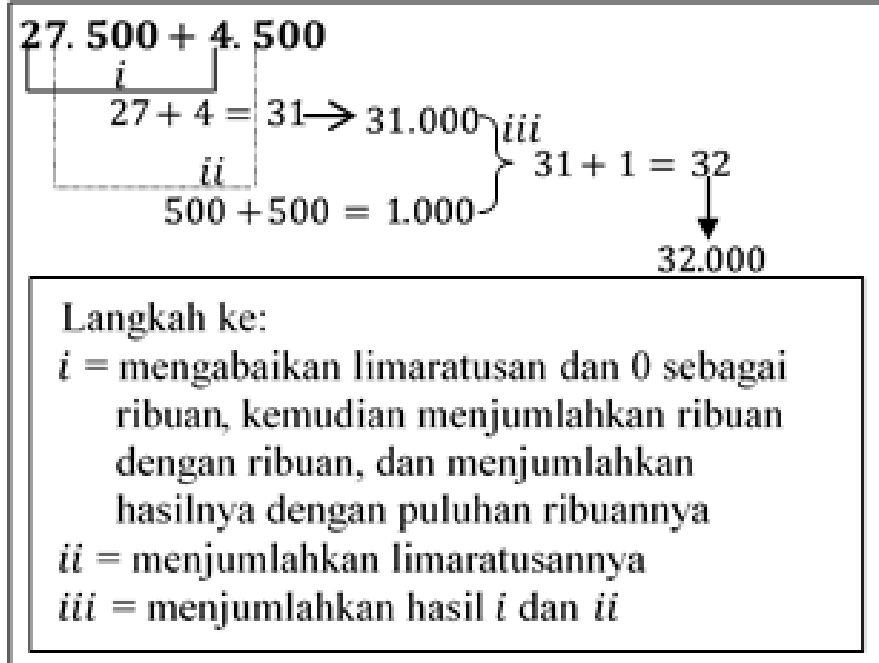

Gambar 7. Cara 1 Penjumlahan

26| Aksioma

Jurnal Pendidikan Matematika FKIP Univ. Muhammadiyah Metro 
ISSN 2089-8703 (Print) Vol. 7, No. 1 (2018)

ISSN 2442-5419 (Online)

Cara kedua, misalnya menghitung $18.500+24.500$. Blijâh menggenapkan 18.500 ke kelipatan 10 diatasnya yaitu 20.000 dengan cara mengambil 1.500 dari 24.500 sehingga $24.500-1.500=$
23.000. Jadi langkah terakhir $18.500+$ $24.500=20.000+23.000=43.000$. Cara pengoperasian tersebut dapat dilihat pada Gambar 8 .

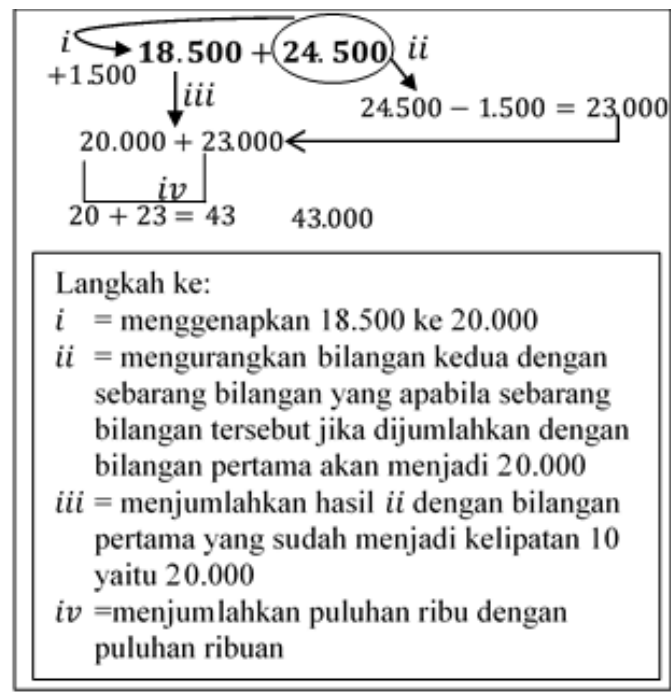

Gambar 8. Cara 2 Penjumlahan

Cara ketiga, misalnya menghitung $23.500+11.500$. Terlebih dahulu blijah mengabaikan limaratusan dan 0 sebagai ribuan, sehingga Blijâh menjumlahkan puluh ribuan yang kedua dengan bilangan pertama yang dijumlahkan yaitu $10+23=33$. Kemudian menjumlahkan bilangan limaratusan dengan bilangan ribuan yang belum dijumlahkan yaitu $500+1.500=2.000$. Sehingga langkah terakhir $33.000+$ $2.000=35.000$. Cara pengoperasian tersebut dapat dilihat pada Gambar 9.

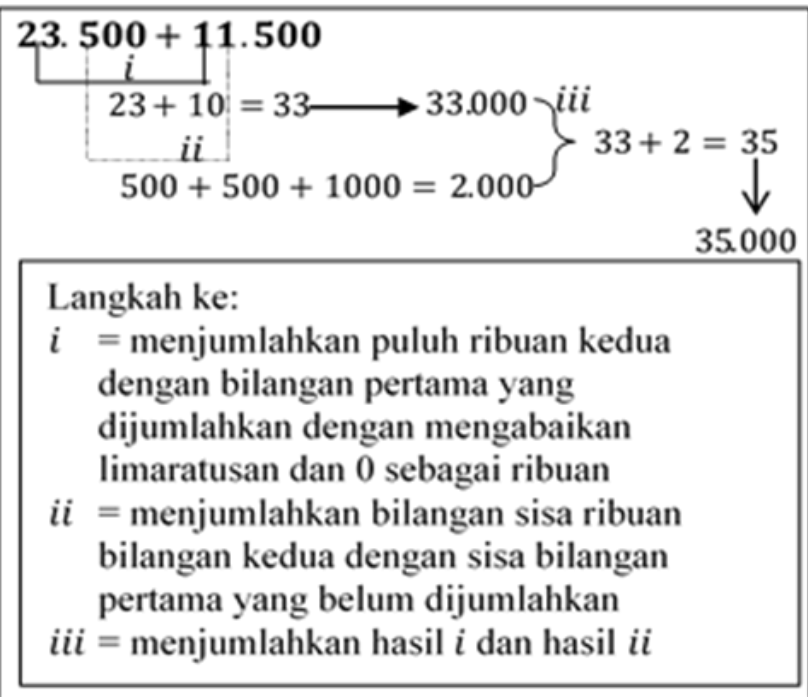

Gambar 9. Cara 3 Penjumlahan 


\section{Pengurangan}

Pengurangan terlihat pada saat pembeli membayar uang kembalian pembeli. Berdasarkan data yang diperoleh di lapangan terhadap kedelapan subjek, cara yang dilakukan untuk menyelasaikan algoritma pengurangan yaitu menggenapkan bilangan pengurangnya ke kelipatan 10 diatasnya dengan cara menambah bilangan tertentu. Misalnya 50.000 $13.000=37.000$ maka cara menghitungnya Blijâh menggenapkan 13 ke 20, menambahkan 7 ke 13, yaitu $13+7=20$, kemudian Blijâh mengurangi 50 dengan 20, $50-20=30$. Sehingga total kembalian yang harus dikembalikan Rp37.000,00. Cara pengoperasian tersebut dapat dilihat pada Gambar 10.

$$
\begin{aligned}
& 50.000-27.000=37.000 \\
& \underset{50-30=20 \quad 30=27+3}{\left.i i i\right|_{20+3}=23} \\
& \text { Langkah ke: } \\
& i=\text { menggenapkan } 27 \text { ke kelipatan } \\
& \text { sepuluh diatasnya yaitu } 30 \\
& i i=\text { mengurangi } 50 \text { dengan } 30 \\
& i i i=\text { menjumlahkan hasil } i \text { dengan } \\
& \text { sebarang bilangan yang menjadikan } 27 \\
& \text { ke kelipatan sepuluh diatasnya }
\end{aligned}
$$

Gambar 10. Pengoperasian Pengurangan

Pada umumnya, sebagian besar Blijâh maupun pembeli cenderung mengabaikan angka 0 sebagai ribuan, puluh ribuan, maupun ratusan ribu. Mereka cenderung mengucapkan 0,1 , $2,3,4, \ldots 9$ untuk ribuan; $10,11, \ldots, 99$ untuk puluhan ribu; serta $100,101, \ldots$, 999 untuk ratusan ribu dengan menggunakan bahasa Madura. Hal ini menarik karena secara tidak langsung mengetahui nilai tempat suatu bilangan karena mereka hanya menyebut puluhan, ratusan atau ribuan saja.

Dalam proses jual beli yang dilakukan Blijâh pada Masyarakat Madura di Problinggo sangat erat kaitannya dengan aktivitas matematika. Hal ini sejalan dengan penelitian Hartoyo (2012) yang menyatakan bahwa meskipun masyarakat tidak paham matematika, namun mereka menerapkan konsep matematika yang rumit diterapkan pada aktivitas kesehariannya. Tanpa disadari Blijâh telah melakukan aktivitas matematika seperti membilang atau menyatakan banyaknya sesuatu terhadap bahan yang hendak mereka jual serta menghitung pada saat transaksi dengan pembelinya. Hal ini sejalan dengan penelitian Ubayanti, Lumbantobing, \& Manurung (2016) dimana para nelayan masyarakat Papua Barat mengem-bangkan aktivitas matematika selama pem-buatan sero Kokas Fakfak seperti pengukuran yang terkait dengan konsep Bilangan dengan menggunakan satuan barang-barang dari bambu dan pembuatan rancangan kapal yang meng-gunakan konsep Geometri. 
Blijâh juga mengembangkan matematika dengan cara mereka sendiri tetapi secara tidak langsung menggunakan konsep matematika yaitu algoritma berhitung untuk menghitung uang kembalian, menghitung laba atau rugi, dan lain-lain. Algoritma berhitung tersebut yang jelas tidak dapat terlepas dari operasi penjumlahan dan pengurangan bilangan.

Berdasarkan deskripsi mengenai cara Blijâh menghitung pada operasi penjumlahan yang dijelaskan di atas, dapat diketahui bahwa ada tiga cara yang dapat dilakukan untuk melakukan operasi penjumlahan. Cara pertama yaitu menjumlahkan berdasarkan nilai tempat. Sebagaimana dengan menjumlahkan puluh ribuan dengan puluh ribuan, menjumlahkan ribuan dengan ribuan kemudian menjumlahkan kedua hasil dari masing-masing penjumlahan tersebut. Hal tersebut juga berlaku untuk penjumlahan bilangan yang salah satunya mengandung unsur limaratusan maupun kedua-nya mengandung unsur limaratusan. Jika bilangan yang dijumlahkan mengandung lima-ratusan, maka dilakukan penjumahan berda-sarkan nilai tempat dan limaratusannya dihitung pada akhir perhitungan yaitu dijumlahkan dengan hasil akhir dari penjumlahan berdasar-kan nilai tempat tersebut. Cara pertama ini sama dengan cara yang diajarkan disekolah yaitu cara bersusun panjang dan bersusun pendek, yang dapat dilihat pada Gambar 11 .

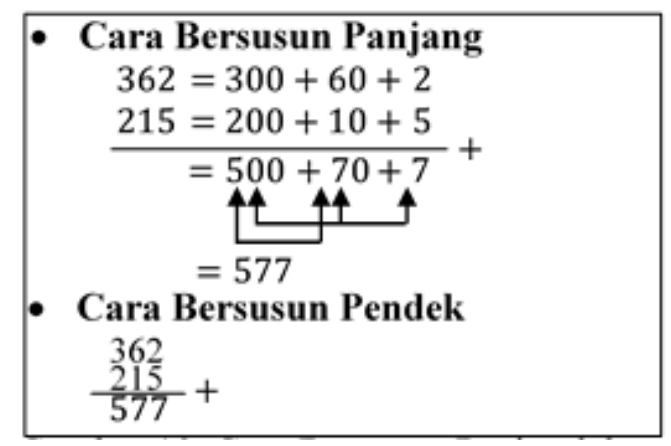

Gambar 11. Cara Bersusun Penjumlahan

Pada cara kedua terdapat perbedaan dengan cara yang diajarkan disekolah. Jika cara di sekolah diajarkan penjumlahan berdasarkan nilai tempat seperti cara pertama, namun beberapa Blijâh menjumlahkan dengan cara menggenapkan bilangan pertama ke bilangan puluhan diatasnya. Kata menggenapkan dalam aktivitas berhitung Blijâh berarti membulatkan bilangan ke kelipatan sepuluh di atasnya. Penjumlahan dengan cara ini biasanya dilakukan jika bilangan pertama yang dijumlahkan adalah bilangan yang dekat dengan pembulatan seperti 16, 27, 38, dan seterusnya yang mendekati ke pembulatan kelipatan sepuluh. Cara yang dilakukan yaitu jika menjumlahkan dua bilangan maka membulatkan bilangan pertama ke bilangan puluhan diatasnya dengan cara bilangan kedua dikurangi dengan bilangan tertentu sedemikian hingga bilangan tertentu tersebut jika dijumlahkan dengan bilangan pertama akan menjadi bilangan kelipatan sepuluh diatasnya. Kemudian kelipatan sepuluh tersebut dijumlahkan dengan bilangan hasil pengurangan bilangan kedua dengan sembarang bilangan tersebut. Cara tersebut juga bisa berlaku untuk penjumlahan salah satunya 
mengandung unsur limaratusan maupun keduanya mengandung unsur limaratusan tanpa harus melainkan limaratusannya. Pada cara ini sejalan dengan strategi dalam estimasi berhitung yang diteliti oleh Salma dan
Amin (2014) yaitu menyelesaikan algoritma penjumlahan dengan adjusting. Model operasi penjumlahan cara kedua ini secara matematis dapat dilihat pada Gambar 12.

$$
\begin{aligned}
& \text { Ribuan Sebagai Satuan } \\
& \qquad \begin{array}{l}
a+b=(a+X)+(b-X) \\
\text { Keterangan: }=Y+(b-X)
\end{array} \\
& X=\text { bilangan tertentu yang dapat membulatkan } \\
& a \text { ke bilangan kelipatan } 10 \text { diatasnya } \\
& Y=\text { bilangan kelipatan } 10 \text { terdekat di atas } \\
& \text { bilangan } a
\end{aligned}
$$

Gambar 12. Model Operasi Penjumlahan

Menurut Thompson (1999), strategi yang dipakai pada operasi penjumlahan di atas dikenal dengan nama bridging through ten dimana Blijâh membuat bilangan pengurang itu menjadi bilangan puluhan yang terdekat (menggenapkan ke bilangan puluhan terdekat). Strategi penjumlahan seperti cara kedua ini dapat digunakan sebagai salah satu strategi untuk memperkuat konsep nilai bilangan puluhan dan memperkenalkan konsep keseimbangan dalam operasi bilangan (balancing) yaitu jika satu bilangan ditambah blangan tertentu makan bilangan lain harus dikurangi bilangan tertentu tersebut.

Pada cara ketiga juga terdapat perbedaan dengan cara yang diajarkan disekolah. Cara yang dilakukan yaitu jika menjumlahkan dua bilangan maka menjumlahkan puluh ribuan bilangan kedua dengan bilangan pertama yang dijumlahkan, kemudian hasil dari penjumlahan tersebut dijumlahkan dengan bilangan tertentu yaitu sisa ribuan pada bilangan kedua. Cara tersebut juga bisa berlaku untuk penjumlahan salah satu bilangan yang dijumlahkan mengandung limaratusan maupun kedua bilangan yang dijumlahkan mengandung limaratusan dengan cara menghitung limaratusnya diakhir operasi perhitungan. Model operasi penjumlahan cara ketiga ini secara matematis dapat dilihat pada Gambar 13.

$$
\begin{aligned}
& \begin{array}{l}
\text { Ribuan Sebagai Satuan } \\
\qquad \begin{aligned}
a+b & =a+(X+Y) \\
& =(a+X)+Y
\end{aligned} \\
\text { Keterangan: } \\
X=\text { bilangan kelipatan } 10 \text { terdekat dibawah } b \\
Y=\text { bilangan tertentu yang diperoleh dari } b-X
\end{array} \\
& \text { Gambar 13. Model Operasi Penjumlahan }
\end{aligned}
$$


Strategi yang dilakukan Blijâh pada Gambar 10 di atas hampir mirip dengan strategi counting on from larger (Thompson, 1999) dimana seseorang menghitung dimulai dari bilangan yang nilainya paling besar. Jadi Blijâh menjumlahkan ribuan kemudian baru menjumlahkan ratusan dalam hal ini lima lima ratusan. Jadi pada strategi ini meliputi tahap decomposing dimana Blijâh memisahkan ribuan dengan ratusan kemudian menjumlahkan bilangan dari nilai yang terbesar kemudian dilanjutkan ke bilangan dengan nilai lebih kecil.

Pada operasi pengurangan yang dilakukan oleh Blijâh terdapat perbedaan dengan yang diajarkan di sekolah. Cara yang diajarkan di sekolah pada umumnya mengurangkan berdasarkan nilai tempat yang dicapai dengan cara bersusun panjang dan bersusun pendek. Sedangkan cara yang dilakukan Blijâh untuk menyelesaikan algoritma pengurangan terdiri dari dua tahap. Tahap pertama yaitu menggenapkan bilangan pengurangnya ke kelipatan sepuluh diatasnya dengan cara menambah bilangan tertentu. Tahap kedua, bilangan tertentu tersebut dijumlahkan dengan bilangan kelipatan sepuluh tersebut. Atau menghitung mundur dari bilangan kelipatan sepuluh diatas bilangan pengurang yang didapat pada tahap pertama. Model operasi pengurangan ini secara matematis dapat dilihat pada Gambar 14.

$$
\begin{aligned}
& \text { Ribuan Sebagai Satuan } \\
& \qquad a-b=a-(b+X)+X \\
& \qquad=(a-Y)+X \\
& \text { Keterangan: } \\
& X=\text { bilangan tertentu yang membulatkan bilangan } \\
& b \text { menjadi kelipatan } 10 \\
& Y=\text { bilangan kelipatan } 10 \text { di atas bilangan } b
\end{aligned}
$$

Gambar 14. Model Operasi Pengurangan

Strategi operasi pengurangan yang dipakai Blijâh hampir mirip dengan strategi yang digunakan pada operasi penjumlahan yaitu menggenapkan ke bilangan sepuluhan di atas bilangan pengurang. Menurut Thompson (1999), strategi ini merupakan perpaduan dari bridging through ten for subtraction (tahap1) dan counting back (tahap 2).

Sekilas algoritma berhitung yang dipakai Blijâh terlihat sederhana tetapi algoritma tersebut melibatkan konsep dan strategi berhitung yang sangat komplek antara lain: konsep keseimbangan dalam berhitung (balancing), konsep nilai tempat, strategi menguraikan nilai (decomposing), dan strategi menghitung dari bilangan yang terbesar, serta mengenapkan ke puluhan di atasnya (bridging through ten). Konsep dan strategi yang digunakan merupakan hal yang penting untuk diketahui dan dipahami siswa di sekolah. Hal ini dapat meningkat kemampuan dan ketrampilan berhitung siswa serta dapat mengasah mental komputasi mereka. Komputasi mental merujuk pada proses menyelesaikan operasi artimatika tanpa menggunkan alat bantu (Sowder, 1988) biasanya perhitungan dilakukan dalam dan dengan pikiran (Heirdsfield, 2003).

Selain itu, penggunaan konteks algoritma Blijâh dalam pembelajaran 
operasi bilangan di kelas dapat memberikan makna kontektual yang relevan dan familiar bagi siswa. Hal ini diharapkan dapat membuat pembelajaran matematika lebih bermakna karena berkaitan dengan konteks keseharian yang mereka temui. Menurut Vallori (2014), pembelajaran bermakna (meaningful learning) dapat meningkatkan pemahaman siswa dibandingkan dengan pembelajaran yang hanya menghafal (rote learning) dalam hal ini menghafal rumus operasi bilangan dan hasil penjumlahan atau pengurangan suatu bilangan. Di sisi lain, konteks algoritma Blijâh juga dapat digunakan sebagai salah satu cara untuk mengintegrasikan budaya dengan pembelajaran di kelas. Integrasi budaya ke dalam pembelajaran di kelas dapat meminimalisir kesulitan siswa belajar matematika (Matang, 2002).

Menimbang manfaat yang dapat diambil dari algortima berhitung Blijâh, algortima ini dapat digunakan sebagai salah satu alternatif pendekatan pembelajaran di sekolah sehingga siswa tidak hanya belajar konsep operasi bilangan tetapi juga strategi dalam menyelesaikan operasi bilangan serta melatih mental komputasi yang diperlukan untuk numerical skills dan number sense.

Dari uraian di atas, beberapa pendekatan cara berhitung yang dilakukan Blijâh berbeda dengan pendekatan cara berhitung yang dipelajari di sekolah. Algoritma atau strategi berhitung mereka sebenarnya merupakan perdaduan dari strategi mental calculation yang sangat sistematis. Hal ini dapat digunakan sebagai alternatif cara mengajar operasi bilangan di kelas sehingga diharapkan dapat memperkaya pendekatan pembelajaran untuk meningatkan numerical literacy dan numerical skills siswa. Dan dalam jangka panjang, jika pendekatan ini digunakan dalam kelas, maka akan dapat melatih mental calculation mereka.

\section{KESIMPULAN DAN SARAN}

Berdasarkan hasil analisis, diperoleh beberapa algoritma berhitung yang terdiri dari penjumlahan dan pengurangan. Dimana dalam algoritma berhitung tersebut terdapat perbedaan dengan cara yang diajarkan di sekolah. Jika di sekolah siswa diajarkan mengoprasikan bilangan dengan cara bersusun panjang dan bersusun pendek, sedangkan Blijâh memiliki cara lain untuk mengoperasikan. Diantaranya pada operasi penjumlahan dengan cara menggenapkan bilangan pertama ke bilangan puluhan diatasnya. Begitupula dengan pengurangan dengan cara menggenapkan bilangan pengurangnya ke kelipatan 10 diatasnya.

Hasil penelitihan ini dapat dijadikan ide alternatif cara atau metode pembelajaran matematika khususnya berhitung. Sehingga siswa dapat mengetahui berbagai macam cara atau strategi berhitung. Selain itu meninjau manfaatnya yang dapat memotivasi peserta didik, guru sebaiknya memperkenalkan nilai-nilai matematika dalam kehidupan sehari-hari pada pembelajaran formal sebagai modal awal mengajarkan konsep matematika kepada siswa. Lebih lanjut, algoritma Blijâh memiliki peluang untuk dapat menjadi salah satu alternatif pendekatan pembelajaran operasi bilangan khususnya operasi penjumlahan dan pengurangan bilangan bulat. Selain untuk memberikan alternatif cara dan strategi berhitung, algoritma Blijah juga dapat digunakan untuk memberikan konteks yang lebih relevan dan dekat dengan kehidupan siswa sehari-hari. 


\section{DAFTAR PUSTAKA}

Barta, J., \& Shockey, T. 2006. The Mathematical Ways of an Aboriginal People: The Northern Ute. Journal of Mathematics and Culture. Vol. 1, No. 1, Hal. 79-89.

Hartoyo, A. 2012. Etnomatematika pada Budaya Masyarakat Dayak Perbatasan Indonesia-Malaysia. Jurnal Penelitian Pendidikan. Vol. 13, No. 1, Hal. 29 - 40.

Heirdsfield, A. M. 2003. "Spontaneous" Mental Computation Strategies. Proceedings of the 27th Conference of the International Group for the Psychology of vMathematics Education Held Jointly with the 25th Conference of PME-NA, 3, 55-62.

Hilbert, J., \& Carpenter, T. P. 1992. Learning with Understanding. In D. A. Grouws (Ed.), Handbook of Research on Mathematics Teaching and Learning. A project of NCTM. New York: Macmillan.

Marzuki. 2011. Meningkatkan Prestasi Belajar Perkalian Bersusun Menggunakan Model Kooperatif TAI pada Siswa Kelas IV SD Negeri 3 Meurah Dua. Lentera Pendidikan. Vol. 11, No. 2, Hal. 31 $-39$.

Matang, R. 2002. The Role of Ethnomathematics in Mathematics Education in Papua New Guinea: Implications for mathematics curriculum. Journal of Educational Studies. Vol. 24, No. 1.

Miles, M. B., \& Huberman, A. M. 1994. Qualitative Data Analysis: An Expanded Sourcebook. 2nd ed. CA: Sage.

Petocz, P., \& Reid, A. 2003. What on earth is sustainability in mathematics ?, 32, 135-144.

Rifai, A. 2007. Manusia Madura. Yogyakarta: Pilar Media.

Salma, U., \& Amin, S. M. 2014. Profil
Kemampuan Estimasi Siswa Sekolah dalam Menyelesaikan Soal Cerita. Jurnal Ilmiah Pendidikan Matematika, 3(1).

Sirate, F. S. 2012. Implementasi Etnomatematika dalam Pembelajaran Matematika pada Jenjang Pendidikan Sekolah Dasar. Lentera Pendidikan. Vol. 15, No. 1, Hal. $41-54$.

Sowder, L. 1988. Children's solutions of story problems. Journal of Mathematical Behavior. Vol. 7, Hal. 227-238.

Sutoko. 1998. Geografi Dialek Bahasa Madura. Jakarta: Ministry of National Education and Culture.

Thompson, I. 1999. Mental Calculation Strategies for Addition and Subtraction (Part 1). Mathematics in School, November, 2-4.

Ubayanti, C. S., Lumbantobing, H., \& Manurung, M. M. H. 2016. Eksplorasi Etnomatematika pada Sero (SET NET): Budaya Masyarakat Kokas Fakfak Papua Barat. Jurnal Ilmiah Matematika Dan Pembelajarannya. Vol. 2, Hal. 11-17.

Vallori, A. B. 2014. Meaningful learning in practice. Journal of Education and Human Development. Vol. 3, No. 4, Hal. $199-209$. 